\title{
The Tongan flying fox Pteropus tonganus: status, public attitudes and conservation in the Cook Islands
}

\author{
Jenny A. Cousins and Steve G. Compton
}

\begin{abstract}
In the Cook Islands the population of Pteropus tonganus tonganus is thought to be declining, but a lack of knowledge of its status, feeding and roosting requirements has precluded effective conservation plans. We surveyed P. t. tonganus on the Cook Islands through observations, counts and interviews with local residents. We estimated the population to be $c .1,730$ on Rarotonga and 78 on Mangaia. A lack of suitable habitat on Mangaia was the most important factor affecting abundance. Overhunting appears to have reduced the populations on both islands. All roost sites were found in undisturbed forest on steep slopes and ridges in the inner and most inaccessible parts of the islands, with roost preference determined by the relative safety from humans
\end{abstract}

rather than food availability. The residents of the Cook Islands seem generally unaware of the serious threat the bats face, with little thought for sustainable hunting. For successful conservation it will be important to alter people's negative perception of these mammals, promoting the value of the bats both ecologically and as a potential source of income from tourists. Habitat protection and enhancement, particularly on Mangaia, will be essential.

Keywords Attitudes, Cook Islands, habitat, Pteropus tonganus, status, Tongan flying fox.

This paper contains supplementary material that can only be found online at http://journals.cambridge.org

\section{Introduction}

Of the 67 species of flying foxes (Family Pteropodidae; Genus Pteropus), 27 are restricted to islands in the Pacific (Simmons, in press). On these islands, in forests with depauperate faunas, it has been hypothesized that flying foxes are the principle pollinators and seed dispersers (Cox et al., 1991; Fujita \& Tuttle, 1991). Given this role, the maintenance of plant diversity and the conservation of natural forest are largely dependent upon bats.

Despite the importance of bats, virtually no baseline population data or monitoring exist for the majority of species (Fujita \& Tuttle, 1991). Although historically abundant on the Pacific islands, there have been numerous accounts of declines in flying fox populations due to overhunting (Wodzicki \& Felten, 1980; Wiles, 1992; Bowen-Jones et al., 1997). Pteropus tonganus tonganus is a subspecies of the Tongan flying fox $P$. tonganus, which has a distribution that includes American Samoa, Cook Islands, Fiji, Niue, Samoa, Tonga, and Wallis and Futuna. Conservation recommendations for $P$. tonganus (Mickleburgh et al., 1992) include a survey of the Cook

Jenny A. Cousins (Corresponding author) 21 Stanmore View, Burley, Leeds, LS4 2RW, UK. E-mail jenny_cousins@hotmail.com

Steve G. Compton Centre for Biodiversity and Conservation, School of Biology, University of Leeds, Leeds, LS2 9JT, UK.

Received 26 January 2004. Revision requested 7 June 2004. Accepted 19 October 2004.
Islands to determine current status and to identify foraging and roosting requirements, as well as a public awareness campaign highlighting the importance of the bats. P. tonganus is not on the IUCN Red List (IUCN, 2004) but its trade is controlled by being on CITES Appendix I.

Located in the South Pacific Ocean, the Cook Islands consist of a Northern Group of six low-lying islands and a Southern Group of nine islands. Only Rarotonga and Mangaia, situated in the Southern Group, currently have flying foxes. Rarotonga is a high volcanic island with a land area of $c .67 \mathrm{~km}^{2}$. Although the habitats on Rarotonga have been greatly altered by human activities, the rugged interior remains largely intact, supporting 105 native flowering plant species (Marshall, 1983). The lowland forests have largely been converted to housing and agriculture. Mangaia is a largely makatea (raised limestone) island with an area of c. $52 \mathrm{~km}^{2}$. Its central volcanic plateau, altered greatly by human activity (Merlin, 1991), is surrounded by a 50-70 m high ring of cliffs of fossilized coral (Steadman, 1985). A plantation of mainly Pinus caribaea (Marshall, 1983) largely covers the volcanic uplands; the majority of the lowlands are swamps of cultivated taro. The human populations on Rarotonga and Mangaia were 11,225 and 1,108 respectively in 1996 (Cook Islands, 2000; Census of Agriculture and Fisheries, 2001).

Flying foxes are the only native mammals on the Cook Islands. Having become extinct in Rarotonga, bats were reintroduced from Mangaia in the 1870s (no further 
details are available; A. Tuara, pers. comm.). A comprehensive survey on Rarotonga in 1997 estimated the population to be 1,784 \pm SE 548 (Kelly \& Bottomley, 1997). There have been no such surveys on Mangaia, although Blackburn (1998), based on discussions with Mangaians, estimated the population to be 500-1,000 individuals.

This study aimed to estimate the population size of $P$.t. tonganus on Rarotonga and Mangaia, to describe habitat preferences, and to identify any major threats. In any conservation initiative it is important to understand the local communities' attitudes towards the focal species, and we therefore also aimed to gain an insight into current public attitudes towards the bats as a basis for future conservation intervention.

\section{Methods}

Fieldwork was carried out between 24 May-6 July 2002. Roosts were found using dusk surveys, local knowledge and previously recorded sightings. As the bats dispersed to forage at dusk, successive nightly surveys mapped the bats' flight paths and determined the general area of a roost. Day transect walks focused on these areas to pinpoint exact locations. Our population estimates are based on counts of dispersal columns from roosts at dusk and day counts. Each roost was counted on five consecutive nights by two observers. Counting started at $c$. 18.00 and continued until all bats had left the roost. The greatest numbers of bats were recorded between 18.11 and 18.41, after which there was a dramatic decline in activity. We were still clearly able to see the bats at this time of day, and are therefore confident that the majority of bats were recorded. A daytime count at each roost gave a second estimate after the dusk counts were completed. Binoculars and a hand tally counter were used for all counting. Five roosts on Rarotonga were identified in this way, with details of four more provided by the Takitumu Conservation Area research officer on Rarotonga. Similar counting techniques were employed by the research officer over a period of 6 months prior to our survey.

Roost trees were identified and type of habitat/land use surrounding the roost, terrain and accessibility were noted. Information on past roosting preferences were obtained from the islands' inhabitants. To gain an insight into the current public attitudes towards flying foxes, two questionnaires were designed (Appendices 1-2), one for the general public and one for school children aged 12-16. Their purpose was to ascertain people's knowledge and awareness of the bats' ecology and status, their attitudes to the bats and the hunting of them, and reactions to potential conservation intervention. Questionnaire design followed standard techniques (Oppenheim, 1992; Foddy, 1993; Gillham, 2002) and was refined through small pilot projects. A total of 100 questionnaires were completed on each island, 40 of these by school children. Fifteen bat hunters on Mangaia and 12 on Rarotonga were among the respondents to the questionnaire. Further information was gathered from influential people such as ministers, mayors, policemen and government officials at either arranged or opportunistic meetings, such as at social occasions.

\section{Results}

\section{Current status and distribution}

There are nine extant roosts on Rarotonga (10-18, Fig. 1) five of which have population estimates made by JAC and four by the Takitumu Conservation Area Research Officer (Table 1). The overall population size is estimated to be c. 1,730, with estimated roost sizes from 15 to 491. The Takitumu Conservation Area has the largest bat populations on Rarotonga. Comparing previously known roosts with the present ones (Fig. 1) it is clear that all were in different locations. Colony 4 , reported to have been stable for many years (G. McCormack, pers. comm.), has now moved. The many new housing developments on Rarotonga are cutting higher into the interior forest, potentially leaving roosts vulnerable to hunting and causing them to move further into the mountains. Shooting was heard most nights in the latter part of the dusk counts, targeting bats that had left their roosts to forage. Colony 7 was seen to abandon its roost following local hunting; it had previously been relatively inaccessible to hunters (in dense vegetation and at a remote location), but the recent clearing of forest and construction of a house had opened up this roost to hunters. One large and previously unrecorded roost (colony 18) was found further up the mountains in dense forest. It is possible that a number of formerly smaller roosts in this area $(5,8$ and 9) have amalgamated into this one relatively large roost that is now in a higher and more isolated location.

Only one roost of c. 78 bats was found on Mangaia (Fig. 2). The consecutive night count results were 70, 79, 80,84 , and 86 bats, and the day count was 76. Bats from this single roost were being hunted at a number of locations around the island.

\section{Habitat preference and fruit availability}

On Rarotonga all roost sites are in relatively undisturbed forest on steep slopes and ridges high up in the mountains. The roosting trees were Cananga ordorata and Cerbera manghas, both tall canopy emergents with sparse leaves. On Mangaia, contrary to previous reports (Wodzicki \& Felten, 1980), flying foxes no longer live on the makatea, but have moved onto the upper plateau, roosting within a deep valley in the area of a plantation. 


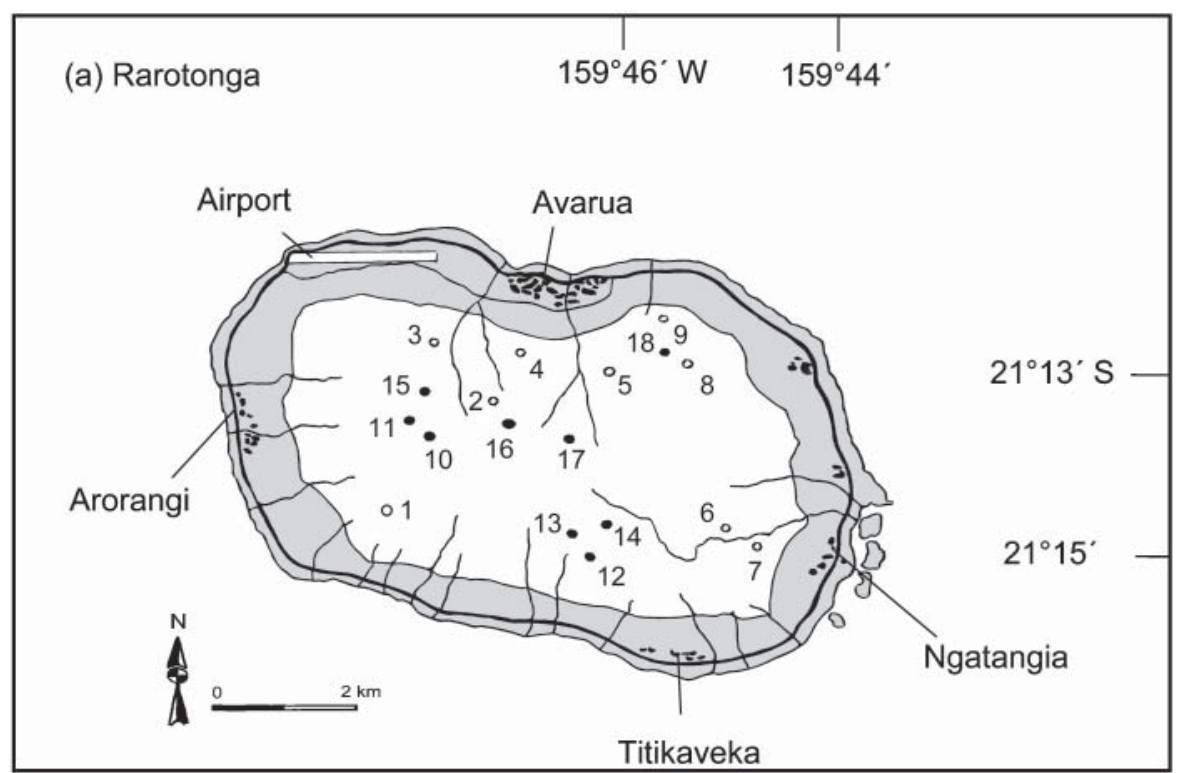

(b) Mangaia

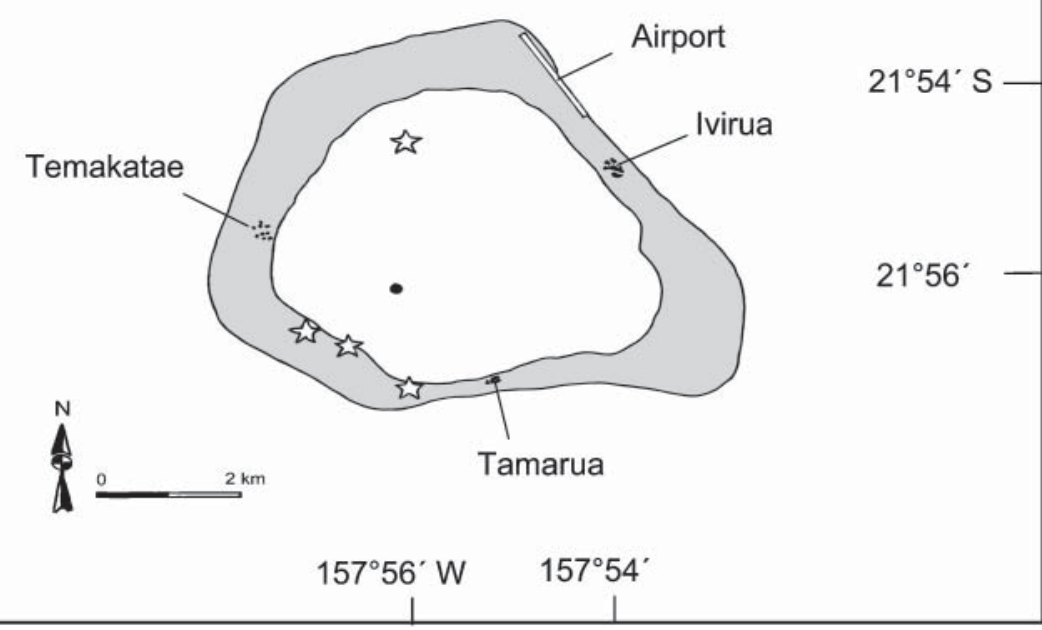

Fig. 1 (a) Rarotonga, showing the location of P. t. tonganus colonies (1-18). White circles represent past colonies (1-9), black circles represent extant colonies (10-18). The white area represents the forested mountainous inner area of Rarotonga, the grey shading the outer flatter area of urban and agricultural land. Bat hunting takes place across the whole of the island. Colonies 12-14 are within the Takitumu Conservation Area. (b) Mangaia, showing the location of the single P. t. tonganus colony represented by a black filled circle. The white area represents the central forested volcanic plateau, the grey shading the lowlands, which mainly comprise cultivated taro and housing. The stars indicate the locations at which bats are commonly hunted whilst flying from their roost at night to feed.

The steepness of the valley sides and the dense vegetation means that this colony is well hidden from view and access is difficult. Once found by hunters, however, the bats would easily be dispersed by the sound of guns firing. Through discussions with c. 80 local people, and having surveyed both the makatea and the area of plantation, it appears that this change in preferred habitat is due to hunting pressure. In the past hunters would regularly find roosts in the makatea but now that the bats have moved, they are less accessible and hunters wait on the roads and tracks for the bats to fly overhead. The colony therefore appears to have found some respite in the plantation area. The dominant species in the plantation is the introduced pine Pinus caribaea, although the bats were found roosting in mature Paraserianthes falcataria, a tall wide-spreading tree. The pines are probably less suitable for bats because of their weaker branches and denser foliage. Neither the roosts in Rarotonga or Mangaia were 
Table 1 Estimated size of the nine colonies of P. t. tonganus on Rarotonga, based on combinations of dusk and day-time counts (colonies 10, $11,15,16$ and 18) and on data from the Takitumu Conservation Officer $(12-14,17)$ (see text for details).

\begin{tabular}{|c|c|c|c|c|}
\hline Extant colony codes & Consecutive dusk counts & Mean dusk counts & Day Counts & Estimated totals \\
\hline 10 & $27,28,31,34,37$ & 31 & 32 & 31 \\
\hline 11 & $17,17,20,14,15$ & 17 & 13 & 15 \\
\hline 12 & & & & 294 \\
\hline 13 & & & & 206 \\
\hline 14 & & & & 491 \\
\hline 15 & $25,25,28,30,29$ & 27 & 31 & 29 \\
\hline 16 & $21,23,26,24,23$ & 23 & 26 & 25 \\
\hline 17 & & & & 457 \\
\hline 18 & $202,211,178,186,176$ & 191 & 172 & 182 \\
\hline
\end{tabular}

situated where there was a high percentage of feeding trees, contrary to the situation reported from other islands (Brooke et al., 2000).

\section{Local attitudes}

Results from the questionnaire suggest that there is more knowledge about the flying fox on Mangaia (Table 2), where more children learn about the flying fox in school and show a greater interest in learning more. Flying foxes are considered to be a nuisance by almost half of the people surveyed on Rarotonga, the commonest reason being the eating of their fruit crops. On Mangaia they are also perceived by some as dangerous, but only when out hunting: 'when the flying fox is still alive, it might bite your hand'. Others, whilst not considering the bats a threat, simply do not like them, regarding them as 'nasty little rat-like creatures'. Despite this, the bats are seen to be important to the islands, especially by the residents of Mangaia, for various reasons. Adults viewed the bats as an important feature of their island and a potential tourist attraction; the children viewed them as a source of food.

Hunting was consistently believed to be the greatest threat to the bats (Table 2), but encouragingly the majority of residents on both islands said they would welcome hunting restrictions, given evidence that flying fox numbers were decreasing. The most common suggestion on both islands was to have a hunting season and a bag limit: 'I am worried that many females will be shot whilst carrying young, because you can't tell the difference between the two whilst hunting, and I therefore think you should only be allowed a few months hunting when they are not breeding or the young are growing'. A complete ban was also suggested on Mangaia: 'Flying fox hunting should be stopped to preserve them for others to enjoy. People will have to accept it'.

The children on Rarotonga showed a keen interest in hunting (Table 2) and a typical view was that it would be fun to kill them'. In contrast a typical response from children on Mangaia was: 'I want to see what the flying fox looks like, where they live and how they eat'. All the bats killed on Rarotonga and Mangaia were killed for personal consumption (Table 2). The bats are more widely eaten on Mangaia, where the residents greatly overestimated the number of bats, and the long-term survival of the flying fox is currently not something that many of the hunters think about.

\section{Discussion}

The population size of $P$. t. tonganus on Rarotonga was c. 1,730 in July 2002, compared to a previous estimate of 1,784 (Kelly \& Bottomley, 1997). The earlier survey did not, however, include the majority of the Takitumu Conservation Area and, given that we found $57 \%$ of the bats roosting there, the earlier count was probably an underestimate. Studies elsewhere have reported that roosts fragment when hunted (Brooke et al., 2000) but on Rarotonga disturbance appears to have resulted in amalgamation in areas of relative safety. Our estimate of the population on Mangaia, c. 78, is much lower but without previous censuses for comparison it is difficult to draw conclusions regarding changes. The available information indicates there has probably been a substantial decline. Archaeological evidence shows decreasing numbers of flying foxes (Steadman, 1985) and discussions with Mangaians also suggest far greater numbers in the past. The nightly hunting on Mangaia poses a great threat to the current population. Assuming that $50 \%$ of the bat population is female, with a reproductive rate of one bat per adult female per year it is feasible that if only one bat is killed per week the population will be extinct within 3 years. This figure is conservative as it assumes that all females will survive to reproduce, that every female reproduces each year, and does not take into account the number of bats that are shot carrying young or other causes of death. In comparison with roosts on other islands, those on the Cook Islands are very small (Mickleburgh et al., 1992), underlining their vulnerability. 
Table 2 Summary of P. t. tonganus questionnaire responses, as percentages. Adults and children were polled separately, with some of the questions in common. A poll specific to hunters was also conducted.

\begin{tabular}{|c|c|c|c|c|c|}
\hline Questions & Responses (\%) & & & & \\
\hline \multicolumn{6}{|l|}{ Adults and children* } \\
\hline What type of animal is the flying fox? & Mammal & Bird & Other & Don't know & \\
\hline Rarotonga & 47,52 & 32,42 & 10,6 & 11,0 & \\
\hline Mangaia & 77,97 & 2,3 & 21,0 & 0,0 & \\
\hline What does the flying fox eat? & Fruit & Leaves & Insects & Other & \\
\hline Rarotonga & 82,53 & 14,35 & 4,12 & 0,0 & \\
\hline Mangaia & 86,94 & 7,6 & 7,0 & 0,0 & \\
\hline $\begin{array}{l}\text { How many flying foxes do you think live on } \\
\text { your island? }\end{array}$ & $0-500$ & $500-1000$ & $1000-5000$ & $5000+$ & Don't know \\
\hline Rarotonga & 32,5 & 0,0 & 42,76 & 5,19 & 21,0 \\
\hline Mangaia & 33,18 & 42,16 & 8,66 & 0,0 & 17,0 \\
\hline & \multicolumn{4}{|c|}{ Rarotonga/Mangaia? } & \\
\hline Rarotonga & 42,38 & 0,10 & 58,52 & & \\
\hline Mangaia & 64,67 & 18,3 & 18,30 & & \\
\hline Are flying foxes a nuisance or danger? & Nuisance & Danger & Neither & & \\
\hline Rarotonga & 43,54 & 0,0 & 57,46 & & \\
\hline Mangaia & 9,36 & 18,27 & 73,37 & & \\
\hline $\begin{array}{l}\text { Would you consider any of the following to be a } \\
\text { threat to the flying fox on Rarotonga/Mangaia? }\end{array}$ & Hunting & Lack of habitat & Other & Don't know & \\
\hline Rarotonga & 61,45 & 34,15 & 5,5 & 0,35 & \\
\hline Mangaia & 62,100 & 16,0 & 22,0 & 0,0 & \\
\hline $\begin{array}{l}\text { Would it upset you if flying foxes disappeared } \\
\text { from Rarotonga/Mangaia? }\end{array}$ & Yes, greatly & Yes, a little & No & & \\
\hline Rarotonga & 53,14 & 37,34 & 10,52 & & \\
\hline Mangaia & 58,63 & 25,33 & 17,4 & & \\
\hline $\begin{array}{l}\text { Would you welcome hunting restrictions if there } \\
\text { was evidence to suggest that flying fox numbers } \\
\text { are decreasing? }\end{array}$ & Yes & No & Don't know & & \\
\hline Rarotonga & 78,47 & 22,16 & 0,37 & & \\
\hline Mangaia & 55,97 & 45,0 & 0,3 & & \\
\hline \multicolumn{6}{|l|}{ Adults } \\
\hline $\begin{array}{l}\text { Have you noticed a change in the number of } \\
\text { flying foxes? }\end{array}$ & Increase & Decrease & No change & Wouldn't notice & \\
\hline Rarotonga & 10 & 25 & 15 & 50 & \\
\hline Mangaia & 8 & 75 & 8 & 9 & \\
\hline Would you encourage future generations to go & Yes & No & & & \\
\hline \multicolumn{6}{|l|}{ hunting? } \\
\hline Rarotonga & 25 & 75 & & & \\
\hline Mangaia & 18 & 82 & & & \\
\hline $\begin{array}{l}\text { Would you be interested in getting involved in } \\
\text { any conservation projects on Rarotonga/Mangaia }\end{array}$ & Yes & No & Don't know & & \\
\hline Rarotonga & 33 & 62 & 5 & & \\
\hline Mangaia & 36 & 64 & 0 & & \\
\hline Have you gone flying fox hunting in the last year? & Yes & No & & & \\
\hline Rarotonga & 20 & 80 & & & \\
\hline Mangaia & 25 & 75 & & & \\
\hline \multicolumn{6}{|l|}{ Children } \\
\hline Have you studied the flying fox in school? & In detail & A little & No & & \\
\hline Rarotonga & 10 & 4 & 86 & & \\
\hline Mangaia & 83 & 10 & 7 & & \\
\hline Would you like to learn more about the flying fox? & Yes, much more & Yes, a little & No & & \\
\hline Rarotonga & 24 & 14 & 62 & & \\
\hline Mangaia & 83 & 10 & 7 & & \\
\hline Have you eaten flying fox? & Yes & No & Don't know & & \\
\hline Rarotonga & 14 & 71 & 15 & & \\
\hline Mangaia & 40 & 60 & 0 & & \\
\hline
\end{tabular}

*Percent responses are provided separately for adults and then children as, for example, 47, 52. 
Table 2 (continued)

\begin{tabular}{|c|c|c|c|}
\hline Questions & Responses (\%) & & \\
\hline $\begin{array}{l}\text { Would you eat flying fox today if it was offered } \\
\text { to you? }\end{array}$ & Yes & No & Don't know \\
\hline Rarotonga & 29 & 52 & 19 \\
\hline Mangaia & 20 & 70 & 10 \\
\hline Would you like to go flying fox hunting? & Yes & No & \\
\hline Rarotonga & 76 & 24 & \\
\hline Mangaia & 33 & 67 & \\
\hline $\begin{array}{l}\text { Would you be interested in working in the field of } \\
\text { animal biology or conservation when you leave } \\
\text { school? }\end{array}$ & Yes & No & Don't know \\
\hline Rarotonga & 7 & 47 & 46 \\
\hline Mangaia & 67 & 20 & 13 \\
\hline \multicolumn{4}{|l|}{ Hunters } \\
\hline How often do you go hunting? & Regularly & Occasionally & Once or twice a year \\
\hline Rarotonga & 40 & 0 & 60 \\
\hline Mangaia & 20 & 60 & 20 \\
\hline Would you have liked to have caught more? & Yes & No & \\
\hline Rarotonga & 60 & 40 & \\
\hline Mangaia & 40 & 60 & \\
\hline $\begin{array}{l}\text { Were the flying foxes you caught for your } \\
\text { personal consumption? }\end{array}$ & Yes & No & \\
\hline Rarotonga & 100 & 0 & \\
\hline Mangaia & 100 & 0 & \\
\hline Do you have regular hunting places? & Yes & No & \\
\hline Rarotonga & 67 & 33 & \\
\hline Mangaia & 100 & 0 & \\
\hline $\begin{array}{l}\text { Is the long term survival of the flying fox something } \\
\text { you think about when you go hunting? }\end{array}$ & Yes & No & \\
\hline Rarotonga & 57 & 43 & \\
\hline Mangaia & 33 & 67 & \\
\hline
\end{tabular}

Whilst bats appear to select roost trees that yield the fruits they eat (Brooke et al., 2000), this was not the case on Rarotonga and Mangaia. On both islands the bats have moved away from their major food sources (agricultural fruits) to the interior of the islands. Roosts were found in relatively undisturbed forests on steep slopes and ridges in the inner and most inaccessible parts of the islands. The largest roosts on Rarotonga were found in the Takitumu Conservation Area where, although there is no law against hunting, it is generally frowned upon to do so. In the Cook Islands roost preference of P. $t$. tonganus therefore appears to be determined by their relative safety from humans and not food availability. In a broad comparison of the fruit available to P. t. tonganus on Rarotonga and Mangaia, there appears to be more fruit (both agricultural and of the forest) available to the bats on the former. Fruit is grown for export as well as local consumption on Rarotonga, and is much more plentiful in the interior of the largely undisturbed forests of Rarotonga than in the pine plantations of Mangaia. For such a small bat population the limited amount of fruits is not currently a problem on Mangaia. On Rarotonga, where there is a larger food source and a much greater area of undisturbed habitat and suitable roosting trees, the bats have bred successfully and increased in numbers following their reintroduction from Mangaia in the 1870s.

The people of Mangaia rely on traditional family smallholdings, and the hunting of bats for food is still frequent. On Rarotonga there is wider-scale farming and, although the hunting of bats is frequent, it appears to have an element of sport. Most hunters reported that bat roosts are becoming increasingly difficult to find and, on Mangaia, low numbers are restricting the number shot. On both islands they also reported that many of the bats taken were pregnant or carrying young.

The children on Mangaia are far more interested in learning about bats, and value them more highly, than children on Rarotonga, probably as a result of learning about bats in school. Islanders seemed generally unaware of the serious threats that the bats are facing, and have little thought for sustainability whilst out hunting. However, the majority said that they would welcome hunting restrictions if there was evidence of a 
decline. A substantial number of people on both islands said that they would be interested in being involved in conservation work.

Through the distribution of the questionnaires and fact sheets used in this study and an article published in the Cook Island News on 14 August 2002 there is now a wider public awareness of the biology, importance and plight of the bats. Both the Mayor and Minister on Mangaia at the time appeared to be supportive of hunting restrictions, but as of December 2004 no such ban is in place (C. Scott, J. Mason, pers. comms.).

Protection of both the bats and their habitat will be necessary to secure the future of P. t. tonganus in the Cook Islands. Flying fox populations are resilient and can recover quickly once hunting ceases (Brooke \& Tschapka, 2000). A valuable Conservation Area is in place on Rarotonga but there are no areas free of disturbance on Mangaia and the pine plantations produce little fruit for the bats to eat. In the longer term a programme of fruit tree planting in this area may be needed to provide food and minimize conflict with farmers. A mixture of species should be planted so that fruit is available all year round. Overall, native fruits provide more variation and have higher average values of several nutrients for fruit bats than do agricultural fruits (Nelson et al., 2000), and native fruit-producing species should therefore be planted.

An education campaign will be vital to the success of any conservation work, and will need to be targeted not only at the general public and school children but also at other groups, such as farmers, fruit growers, forestry, the building industry and local and national governments, who may have impacts on the bats. Involvement within the community was found to be very important to the success of our project, and this should be noted for any future conservation work on the islands. Much benefit could be gained from exposing secondary school children to tame bats, some of which are kept as pets by the islanders. Perceptions of these mammals may also be influenced by a wider recognition of their potential for income generation from tourists, particularly on Mangaia, where tourism is currently limited. If the proposed hunting restrictions are effective the bats may become as habituated to people as those on Tonga, where the bats are considered to be sacred and only royalty are allowed to hunt them or harm them in any way. Habituation would allow more ready access to roosts, making ecotourism more attractive.

Flying foxes play an important role in tropical ecosystems. On islands with depauperate faunas such as Mangaia and Rarotonga it has been hypothesized that fruit bats are vital pollinators and seed dispersers (Cox et al., 1991), and crucial for the preservation of highly endemic island flora. The declining populations of P.t. tonganus on Rarotonga and Mangaia could have serious implications for forest regeneration. The protection and long-term preservation of fruit bat populations therefore needs to be an essential component of conservation programmes in the Cook Islands.

\section{Acknowledgements}

Our thanks to Professor John Altringham for sharing his expertise in the early stages of this research, to Gerald McCormack (Cook Islands Natural Heritage Project), Iti (Takitumu Conservation Area research officer) and Allan Tuara (local naturalist, Mangaia) for sharing their knowledge and support, and to the many willing volunteers who completed our questionnaires and spent time talking to us. JAC would like to thank Samantha Buxton for her never-ending enthusiasm for climbing mountains and hiking across ridges in the search of bats. Gratitude also goes to Toby Gamlen for his constructive comments and continued support.

\section{References}

Blackburn, R. (1998) Moa kirikiri - the flying fox. In Environmental Concerns in the Cook Islands (eds A. Tiraa \& E. Smith), pp. 12-23. Takitumu Conservation Area Project, Cook Islands.

Bowen-Jones, E., Abrutat, D., Markham, W. \& Bowe, S. (1997) Flying foxes on Choiseul (Solomon Islands) - the need for conservation action. Oryx, 31, 209-217.

Brooke, A., Solek, C. \& Tualauleleui, A. (2000) Roosting behaviour of colonial and solitary flying foxes in American Samoa (Chiroptera: Pteropodidae). Biotropica, 32, 338-350.

Brooke, A. \& Tschapka, M. (2002) Threats to overhunting the flying fox, Pteropus tonganus, (Chiroptera: Pteropodidae) on Niue Island, South Pacific Ocean. Biological Conservation, 103, 343-348.

Cox, P.A., Elmqvist, T., Pierson, E.D. \& Rainey, W.E. (1991) Flying foxes as strong interactors in South Pacific island ecosystems: a conservation hypothesis. Conservation Biology, $5,448-454$

Foddy, W. (1993) Constructing Questions for Interviews and Questionnaires. Theory and Practice in Social Research. Cambridge University Press, Cambridge, UK.

Fujita, M.S. \& Tuttle, M.T. (1991) Flying foxes (Chiroptera: Pteropodidae): threatened animals of key ecological and economic importance. Conservation Biology, 5, 455-463.

Gillham, B. (2000) Developing a Questionnaire. Continuum, London, UK.

IUCN (2004) 2004 IUCN Red List of Threatened Species. IUCN, Gland, Switzerland [http:/ / www.redlist.org, accessed 6 January 2005].

Kelly, L. \& Bottomley, C. (1997) Conservation in the Cook Islands - Final Report of a Research Expedition to the Cook Islands, South Pacific, to Study the Mangaia Kingfisher and Pacific Fruit Bat. Unpublished Report in conjunction with the Cook Islands Natural Heritage Project, supported by the Royal Geographical Society, London, UK.

Marshall, A.G. (1983) Bats, flowers and fruits: evolutionary relationships in the Old World. Biological Journal of the Linnean Society, 20, 115-135. 
Merlin, M.D. (1991) Woody vegetation on the raised coral limestone of Mangaia, Southern Cook Islands. Pacific Science, 45, 131-151.

Mickleburgh, S.P., Hutson, A.M. \& Racey, P.A. (eds) (1992) Old World Fruit Bats: An Action Plan for their Conservation. IUCN/ Species Survival Commission Chiroptera Specialist Group, IUCN, Gland, Switzerland.

Nelson, S.L., Miller, M.A., Heske, E.J. \& Fahey Jr, G.C. (2000) Nutritional consequences of a change in diet from native to agricultural fruits for the Samoan fruit bat. Ecography, 23, 393-401.

Oppenheim, A.N. (1992) Questionnaire Design, Interviewing and Attitude Measurement. Printer Publishers, London, UK.

Rainey, W.E. \& Pierson, E.D. (1992) Distribution of Pacific Island flying foxes. In Pacific Island Flying Foxes: Proceedings of an International Conservation Conference (eds D.E. Wilson \& G.L. Graham), pp. 53-60. US Fish and Wildlife Service Biological Report 90(23). US Department of the Interior, Fish and Wildlife Service, Washington, DC, USA.

Simmons, N.B. (in press) Order Chiroptera. In Mammal Species of The World: A Taxonomic and Geographic Reference. Third Edition (eds D.E. Wilson \& D.M. Reeder).

Steadman, D.W. (1985) Fossil birds from Mangaia, Southern Cook Islands. Bulletin of the British Ornithologists Club, 105, 58-66.

Wiles, G. J. (1992) Recent trends in the fruit bat trade on Guam. In Pacific Island Flying Foxes: Proceedings of an International Conservation Conference (eds D.E. Wilson \& G.L. Graham), pp. 53-60. US Fish and Wildlife Service Biological Report
90(23). US Department of the Interior, Fish and Wildlife Service, Washington, DC, USA.

Wodzicki, K. \& Felten, H. (1980) Fruit bats of the genus Pteropus from the islands Rarotonga and Mangaia, Cook Islands, Pacific Ocean. Senckenbergiana Biologica, 61, 143-151.

Woonton, R. (2001) Cook Islands 2000 Census of Agriculture and Fisheries. Cook Islands Government Ministry of Agriculture, Cook Islands.

\section{Appendices 1-2}

The appendices for this article are available online at http://journals.cambridge.org

\section{Biographical sketches}

Since the completion of this project Jenny Cousins has worked as a field assistant in a long term research project to help conserve the cheetah in Botswana.

Steve Compton is interested in plant-animal relationships, particularly fig trees, their pollinators and seed dispersers. In the UK he acts as lead partner for several plant-eating beetle species listed on the Insect Biodiversity Action Plan. 